\title{
ECONOMICS
}

\section{BIASES IN PATENT EXAMINATION AND FIRMS' RESPONSES: EVIDENCE FROM THE PHARMACEUTICAL INDUSTRY}

by

Fei Yu

Tsinghua University, China

and

Yanrui Wu

Business School

University of Western Australia 


\title{
BIASES IN PATENT EXAMINATION AND FIRMS' RESPONSES: EVIDENCE FROM THE PHARMACEUTICAL INDUSTRY
}

Fei Yu, Tsinghua University (yufeipublish@outlook.com)

Yanrui Wu, University of Western Australia (yanrui.wu@uwa.edu.au)

\section{DISCUSSION PAPER 16.06}

\begin{abstract}
Empirical analysis of matched patent application data in the world's major patent offices has shown considerable variation in patent granting probability and examination duration across different countries. This phenomenon is attributed to institutional misclassifications or patent examiners' mistakes by some authors. Others argued that cross-country heterogeneity could also be caused by deliberate manipulation of patent examination procedures with the goal to foster native inventors through oppressing foreign patent applicants. To explore whether manipulation exists, this study presents a case study of pharmaceutical patents granted by the US patent office and approved by the US FDA. Especially it focuses on the filing behavior of pharmaceutical companies in Korea, Japan and China. The regression results show that the granting ratio of the previous applications of a foreign company is correlated with the company's probability of lodging a new patent application, which provides a supplementary evidence of the existence of the manipulated patent examination procedures.
\end{abstract}

Key words: Patent examination, Non-national treatment, Pharmaceutical industry JEL codes: O34, O38 


\section{Introduction}

Empirical studies have shown significant heterogeneity in patent granting probability and examination duration across different countries. In certain countries it seems foreign patents receive lower granting probability and longer examination duration than domestic applications. For example, Kotabe (1992) argues that the Japanese patent office seems to enforce longer pendency periods for foreign applicants than domestic applicants. Webster et al. (2007) claim that foreign patent applications in the Japanese patent office are less likely to be granted than Japanese ones, and that US patent applications in European patent offices also have relatively low grant probability. Yang (2008) reckons that the US patent office seems to treat domestic and foreign applications equally while the Chinese patent office appears to treat domestic applications preferentially.

Many researchers have attempted to explain why applications for the same patent lodged in different national patent offices could receive dissimilar treatment. The literature can be broadly divided into two camps. One camp regards the cross-country variation as human "errors" such as institutional misclassifications or patent examiners' mistakes (e.g. Lemley and Sampat, 2012; Palangkaraya et al., 2011). The other camp claims that it could be caused through intended manipulation against foreign patent applicants with the goal to foster native inventors. For instance, Yu and Wu (2013) investigate how a domestic patent office could affect a domestic firm's profit by changing the pendency and granting probability of a foreign firm's patent application. Thus, preferential treatment towards domestic patent applications could help the domestic firm to catch up or even leapfrog its foreign counterparts’ advanced technology.

Whether manipulation exists in patent examination procedure thus becomes an important research 
topic. Previous studies on this issue mainly compare patent examination results across different patent regimes. However, these results are often challenged by an identification issue. That is, we need to distinguish deliberate discriminatory policy from non-intended barriers such as linguistic and cultural obstacles. As illustrated in the trade literature, foreigners could be in a disadvantaged position due to these obstacles (Konya, 2006; Melitz, 2008; Egger and Lassmann, 2012). Further, foreign firms in non-English-speaking countries seem to be affected more by the language barrier than those in English-speaking countries. For instance, there is less trade between the US and a country whose language is more distinguished from English (Hutchinson, 2005). Therefore, the lower granting ratio or longer pendency for foreign patent applications in certain countries could be merely a result of language and cultural obstacles.

This study differs from the existing literature by focusing on the firms' response to potential discrimination in the patent sector. We explore whether foreign firms respond by not filing for patent applications if they are aware of non-national treatment. Previous studies demonstrate that deliberate non-national treatment is more likely applied to foreign patents which are (1) profitable inventions, (2) associated with the high-tech industries and (3) related to the fields with low concentration of native patents. In particular the patent offices in Japan, Korea and China are suspicious of adopting discriminatory patent policies (Kotabe, 1992; Webster et al., 2007; Yang, 2008; Yu and Wu, 2013). Thus this study focuses on the filing of pharmaceutical patents in these three countries.

The pharmaceutical industry is a typical R\&D intensive industry with both risks and prospects. As a consequence, incumbent firms usually hold the dominant position in the market. Taking China as an 
example, Chen and Zhang (2006) find American pharmaceutical companies dominate patent applications in this country. In addition, patent value for Chinese owners is much lower than that for the overseas owners (Zhang and Chen, 2012). Given these observations, some researchers argue that high patent protection would either have negative impacts on the pharmaceutical industry, or simply not stimulate domestic innovation as intended (Qian, 2007; Li, 2008). Therefore, if discriminatory patent policy exists in a country, it is expected to occur on a larger scale in the pharmaceutical industry.

The regression analysis in this study is based on a matched pharmaceutical patent filling dataset. The results demonstrate that the granting ratio of the previous applications of a foreign company is correlated with the company's probability of lodging a new patent application. Thus if a country adopts a discriminatory patent policy, foreign inventors will less likely lodge new applications in this country. The rest of the paper begins with an overview of the characteristics of pharmaceutical patents in China (Section 2). The database is then narrowed down to a smaller size with mainly high quality patents (Section 3). With this refined dataset, an econometric framework is designed to investigate the patent filling behavior in Section 4. Section 5 discusses the regression results and provides the robustness checks, followed by some final conclusions in Section 6 .

\section{Pharmaceutical Patents in China}

The patent application data is extracted from the Worldwide Patent Statistical Database (also known as PATSTAT) maintained by the European Patent Office (EPO). This database covers about 70 million patent records from over 80 countries. In this section, Chinese pharmaceutical patents for invention are analyzed. Pharmaceutical patents are marked with the International Patent 
Classification (IPC) subclasses A61 and C07. The former code explains the medical use of drugs while the latter code reflects the chemical structure of drugs. However, as the IPC code document explains that the "therapeutic activity of compounds is further classified in subclass A61P" (WIPO, 2016, p.4). This covers drugs under the codes C07C and C07D. For this reason, patents considered in this paper all fall under A61 subclass and should be fairly representative of all pharmaceutical patents. In general the A61 category contains patents of preparation for medical, dental and toiletry purposes. Patents are deleted if they fall in the subclass of dental preparations (A61K 6/00), cosmetics and perfumes (A61K 8/00) and Chinese traditional herbal medicines (A61K 36/00, 125/00, 127/00, 129/00, 131/00, 133/00 and 135/00).

During the period of 1984-2009, 92,753 Chinese pharmaceutical patents were recorded in the PATSTAT database, representing $0.96 \%$ of the total Chinese patents for invention that have been filed. Figure 1 shows that the increase of the number of pharmaceutical patents in China is relatively slower than that in other industries. Figure 2 demonstrates the origins of pharmaceutical patents registered in China. Major foreign applications are from the US, EPO member countries and Japan. It is important to note that because the PATSTAT database doesn't record patents in most recent years, this lag of data collection causes a downfall in the number of patents since 2007. 


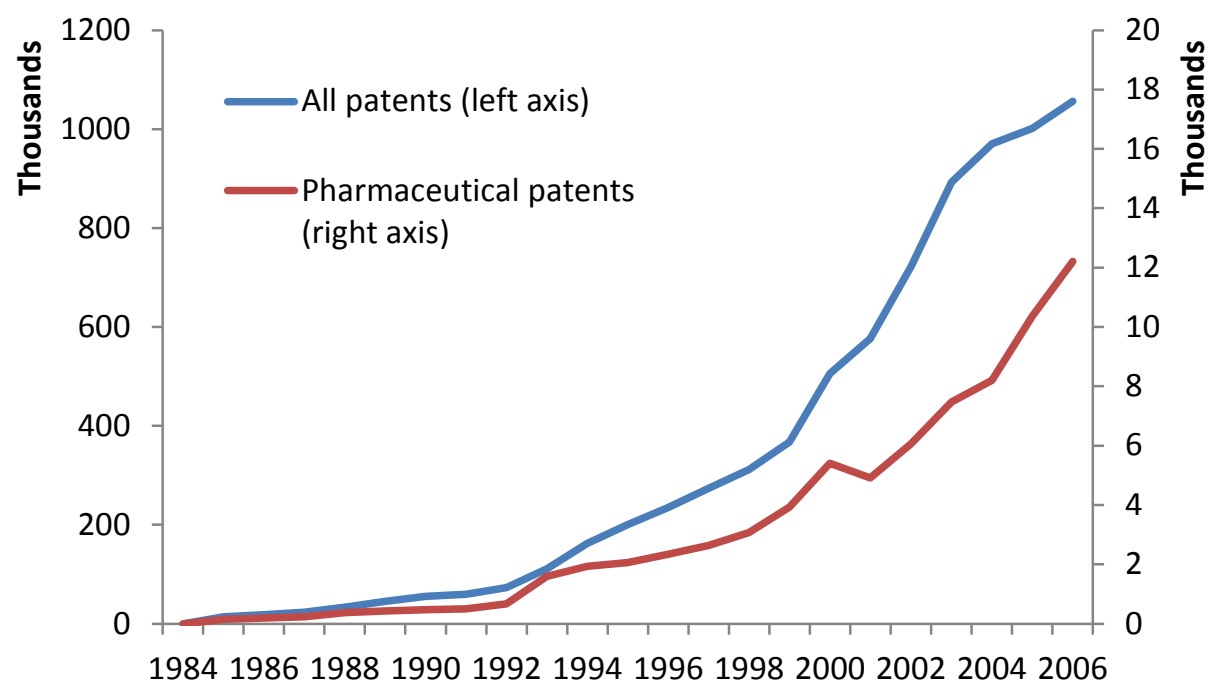

Source: Authors’ own calculations using the PATSTAT database.

Figure 1 The number of patent applications in the Chinese patent office

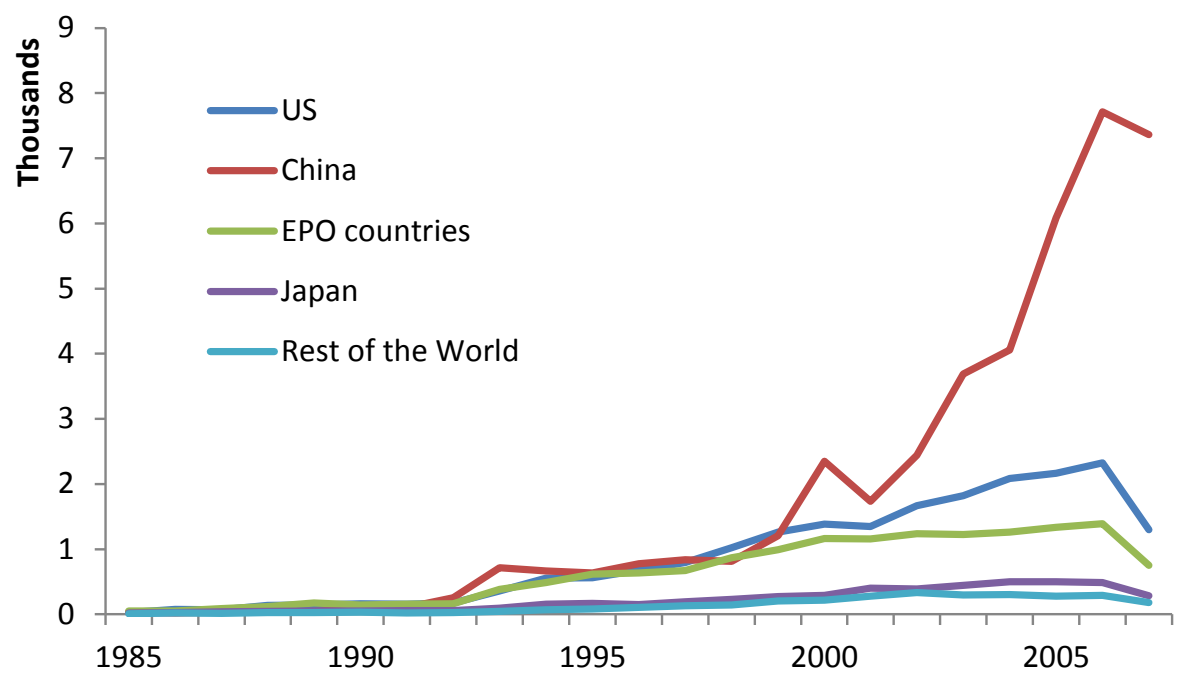

Source: Authors' own calculation using the PATSTAT database.

Figure 2 China's pharmaceutical patent applications by country

Pharmaceutical patents are also distinguished by their therapeutic activities in the IPC subclass A61P. Figure 3 shows that the majority of the patent applications belongs to drugs for disorders of the alimentary tract or the digestive system (A61P 1/00), antineoplastic agents (A61P 35/00), anti-infectives (A61P 31/00), drugs for disorders of the metabolism (A61P 3/00), drugs for 
disorders of the cardiovascular system (A61P 9/00) and drugs for disorders of the nervous system (A61P 25/00).
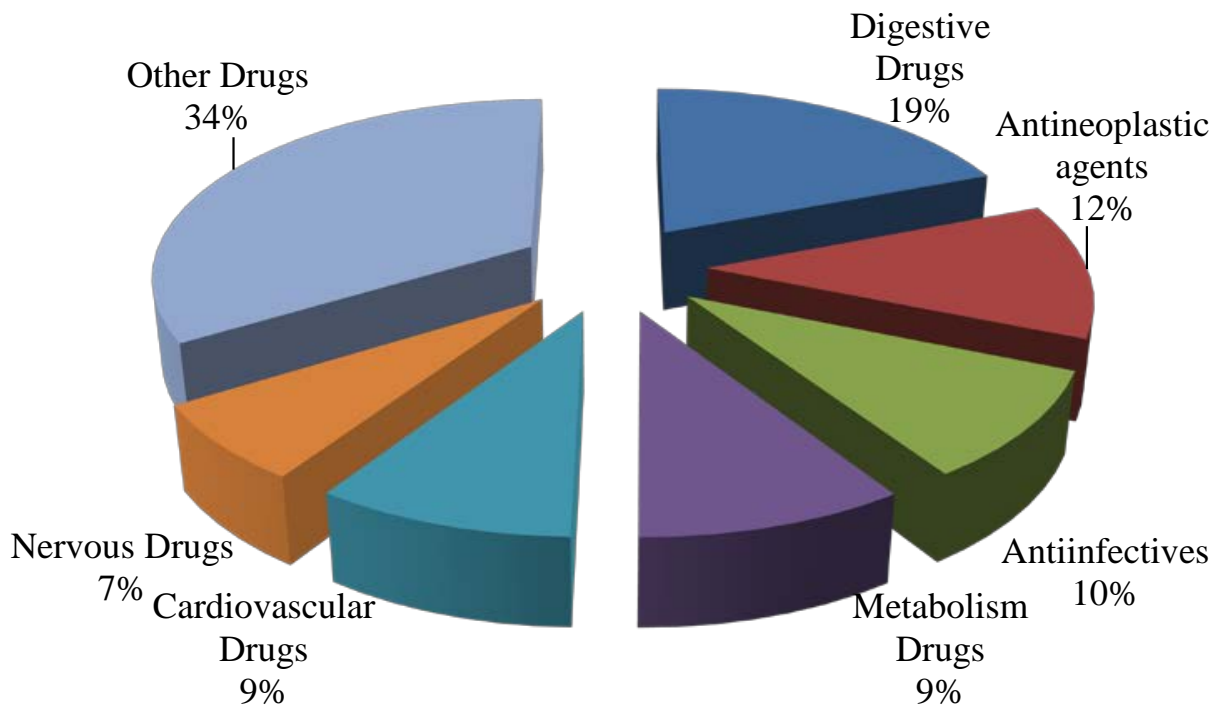

Source: Authors' own calculation using the PATSTAT database.

Figure 3 The therapeutic distribution of drug patent applications in China

These patents can be further categorized according to the characteristics of the applicants, that is, patents invented in the US, EPO countries and Japan; and those owned by Chinese individuals, corporations, or non-profit organizations (NPO) such as universities and hospitals. Figure 4 demonstrates the trend of patent applications and granted patents. There are two abnormal observations in the years 2000 and 2001 (Figure 4a). ${ }^{1}$ If these two abnormal observations are excluded, it is found that the growth of Chinese inventions has gained momentum since 2000, with

\footnotetext{
1 The first one is due to a single company, Shanghai Bode Gene Development Co. Ltd., which in total lodged 1,815 patent applications. Those patents are simply new discoveries of human genome sequencing research, and most of these applications were eventually rejected. The second abnormality is a similar example of flood filing by an individual inventor, Mengjun Yang. He lodged 945 patent applications of nano-scale versions of traditional Chinese medicinal herbs "by simply turning traditional plants into fine powders with particles under 100 nanometres and claiming a new invention with increased solubility and bioavailability” (See http://www.captainhookawards.org/winners/2004_pirates).
} 
corporations playing a greater role than NPOs.
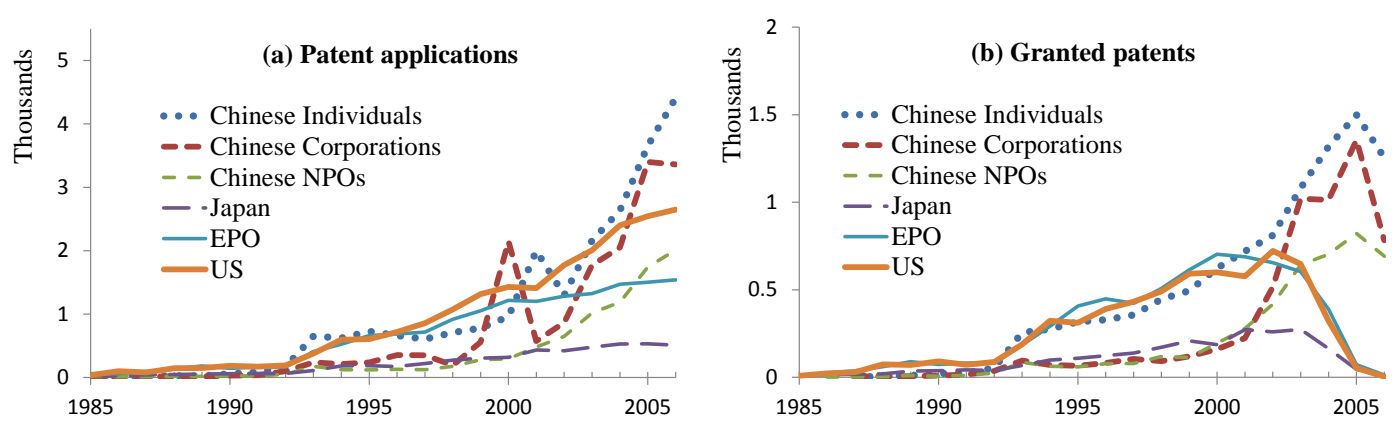

Source: Authors' own calculation using the PATSTAT database.

Figure 4 Patents registered in China by origin of owners

Figure $4 \mathrm{~b}$ demonstrates the number of granted patents during 1985-2006. In this table the time or $\mathrm{X}$-axis is not the year when a patent is granted (or rejected), but the year when a patent application is lodged. Thus the $\mathrm{X}$-axis in Figure $4 \mathrm{~b}$ is the same as the time axis in Figure 4a. It is clearly shown that the two abnormal sets of applications are largely rejected because there are no abnormal spikes of granted patents in the following years.

Figure $4 \mathrm{~b}$ implies that the native inventors in China are likely to receive preferential treatment. Up until the year 2010 (when the version of the PATSTAT database used in this paper is published), the number of granted foreign patents lodged between 2002 and 2005 declined, while the number of granted Chinese patents in the same period increased. Since both the foreign and native applications increased in these years (see Figure 4a), the decline of the number of granted foreign patents can only happen if foreign applications are being rejected at a higher rate than native applications or if the examination period of foreign applications is prolonged. The latter case can occur because the patent data in Figure 4b is truncated. For example, if a patent is granted after 2010, then its granting is not recorded in the version of PATSTAT used in this paper and thus this patent is not shown in Figure 4b. Accordingly, patents granted with a longer delay are not fully captured in Figure 4b. 
Nonetheless, either a foreign applications are rejected in a higher rate or approved with longer examination durations is a sign of possible non-national treatment. This question will be explored further in the empirical analysis.

If foreign patents experience non-national treatment, are the applicants aware of this unfair treatment? Will they retaliate by not lodging new patent applications which they expect to be rejected? To answer these questions, other factors that can affect patenting behavior need to be controlled for. One is the quality of the rejected patent applications. If the rejected patent applications are expected with a high rejection rate due to the poor quality of the patent, then the applicants would unlikely relate the rejection to unfair treatment. Another factor is applicant's outreach capacity. If a multinational company has a subsidiary in the target country, the subsidiary can facilitate the application for patents in the host country. To control for these factors, refined high-quality patent data as well as firm specific information is needed. Therefore, the next section discusses how to further reduce the pharmaceutical patent data for econometric analysis.

\section{FDA Approved Drugs}

A unique characteristic of pharmaceutical patents is that not all patents become commercial products, because before those drugs are sold in the market they need to be approved by regulatory authorities. In the United States, the authority is known as the Food and Drug Administration (FDA). The FDA publishes approved patents in a book named the Approved Drug Products with Therapeutic Equivalence Evaluations, or as it is more easily referred to, the Orange Book. The Orange Book is updated every month. In the March/2012 edition it lists 9,253 approved drugs, which are matched with 2,334 patents. 1,994 of them are also documented in the PATSTAT 
database.

How many of those 1,994 pharmaceutical patents are also filed in other countries apart from the US? To answer this question, those patents need to be matched with patents for the same inventions which are lodged outside the US. The matching method is based on priority rights. An invention can only receive legal protection in a country if it is granted a patent by the patent office in that country. The priority right allows the claimant to file a subsequent application in another country for the same invention, effective as of the date of filing the first application. When filing the subsequent application, the applicant must claim the priority of the first application in order to make use of the right of priority. Patents registered across countries for the same invention are called a patent family, which can be tracked by examining priority rights.

Figure 5 shows the match of the patents by priority links (first-order patents). The first-order priority links do not exhaust all the patents in the patent family. For example, patent A registered in the FDA Orange Book may not be the first patent application lodged in the US patent office. Its priority claim can be patent B, which was lodged earlier than application A. Thus, if the inventor wants to claim the priority in another country, they will more likely claim priority using patent B rather than patent A. In this case, the second-order priority link can be helpful. For instance, if a patent $\mathrm{C}$ is lodged in Japan and the priority listed is patent $\mathrm{B}$, it is still put in the same patent family with patent A. Similarly, the third-order priority link happens if a patent D only claims patent C as its patent priority. Figure 5 shows that a third-order priority link is very rare. Thus, the checking of higher-order links is not required. 


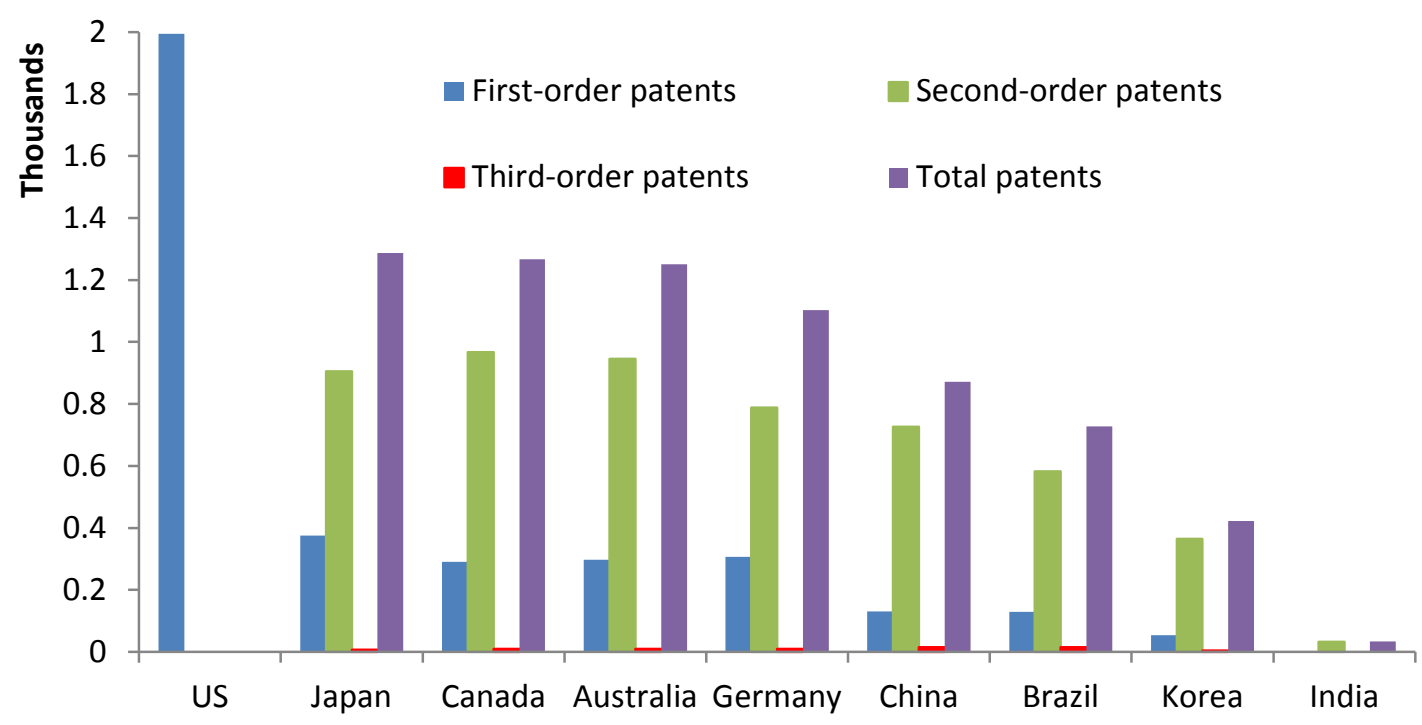

Source: Authors' own calculation using the PATSTAT database.

Figure 5 FDA patents registered in selected countries

Cross-country patent links can be used to explore how protective patent policy affects foreign patent applicants' decisions of filing new applications. Figure 5 shows that not all FDA-approved patents are registered in other countries. The potential market size for the product may be a reason for this. However, there are other reasons that must be looked at. For example, a very limited number of patents are registered in India compared to China and Brazil. The fact that India is one of the world's biggest generic drug exporters may imply that the protection level of intellectual property also can affect a firm’s filing strategy.

In this paper we argue that firms may react to the protectionism in a foreign patent office by filing fewer applications. However, an essential question may rise concerning the behavior of firms. If a firm is aware of the protectionism in country $\mathrm{X}$ (possibly from the experience of its previous applications), then what makes the firm to stop or continue lodging patent applications in the future? Given the fact that this firm's patents are granted somewhere else, all patent documents are placed in the public domain. Then it seems that this firm has nothing to gain from stopping lodging patent 
applications in country X. In practice, however, “stopping” may happen for at least two reasons. First, if the firm foresees very low grant probability in country $X$, then the firm can save the application fee and other fees (such as fees paid to a local agent for preparing applications, as well as translation fees) by not lodging further applications there. Studies on this topic suggest a range of fees affect the behavior of applicants (Rassenfosse and van Pottelsberghe, 2013). The laxity of fee policies adopted by the US, European and Japanese patent offices contributed to a significant extent to the rising propensity to patent (Rassenfosse and van Pottelsberghe, 2012; Danguy and van Pottelsberghe, 2011). Second, by containing patent information in a specific language domain (for example, only in English), then foreign counterparts may have to pay a high searching cost to obtain the information of a particular invention in English. An extreme example is India, where patents on medicines are not recognized before 2005, and Figure 5 just demonstrates how this policy affects the application rate.

If firms do react to the protectionism in a foreign patent office by filing fewer applications, then how is firms' filing behavior determined? It needs be analyzed by the potential revenue and costs of filing. On the one hand, the revenue is the monopolistic profit that a patent can bring to the company, which is affected by the market size of the specific pharmaceutical product. It is also determined by the protection level of intellectual property. A less strict patent law environment will create a larger room for counterfeiting, which will undermine patent owners' profitability. On the other hand, the cost of lodging a transnational patent application is related to the disadvantages faced by foreign applicants, such as cultural and language barriers. However, multinational corporations (MNCs) can partly reduce such costs, thanks to the presence of their subsidiaries in the host country. Furthermore, bigger companies may be able to cope with a larger entry cost. These 
factors should be taken into consideration in the empirical modeling exercises.

\section{Econometric Model and Data}

The existing research suggests that the patent offices in China, Japan and Korea may employ discriminatory patent policies (Kotabe, 1992; Webster et al., 2007; Yang, 2008; Yu and Wu, 2013). Thus this study focuses on the FDA-approved patent applications lodged in these three countries. Let appln_times ${ }_{i}$ be an ordered response for patent $i$ and it takes one of the four values $\{0 ; 1 ; 2 ; 3\}$. appln_times $_{i}=0$ if patent $i$ is not lodged in any of the patent offices, appln_times ${ }_{i}=1$ if it is lodged in only one country, appln_times ${ }_{i}=2$ if it is lodged in two countries and appln_times ${ }_{i}=3$ if it is lodged in all the three patent offices. The ordered Logit model for appln_times (conditional on a set of explanatory variables, $\mathbf{X}$ ) can be defined as (Wooldridge, 2002, p.504):

$$
\begin{aligned}
& P(\text { appln_times }=0 \mid \mathbf{X})=\frac{1}{1+\exp \left[-\left(\alpha_{1}-\mathbf{X}^{\prime} \mathbf{B}\right)\right]} \\
& P(\text { appln_times }=1 \mid \mathbf{X})=\frac{1}{1+\exp \left[-\left(\alpha_{2}-\mathbf{X}^{\prime} \mathbf{B}\right)\right]}-\frac{1}{1+\exp \left[-\left(\alpha_{1}-\mathbf{X}^{\prime} \mathbf{B}\right)\right]} \\
& P(\text { appln_times }=2 \mid \mathbf{X})=\frac{1}{1+\exp \left[-\left(\alpha_{3}-\mathbf{X}^{\prime} \mathbf{B}\right)\right]}-\frac{1}{1+\exp \left[-\left(\alpha_{2}-\mathbf{X}^{\prime} \mathbf{B}\right)\right]} \\
& P(\text { appln_times }=3 \mid \mathbf{X})=1-\frac{1}{1+\exp \left[-\left(\alpha_{3}-\mathbf{X}^{\prime} \mathbf{B}\right)\right]}
\end{aligned}
$$

where $\alpha_{1}, \alpha_{2}$ and $\alpha_{3}$ are unknown cut points to be estimated and $\mathbf{B}$ stands for the vector of coefficients.

The explanatory variable $\mathbf{X}$ includes the potential revenue and costs. As mentioned before, the revenue is affected by the market size of the specific pharmaceutical product (market_size). Ideally, the market size should be measured by sales of the drugs in Japan, Korea and China, respectively. 
However, the drug sales data in these countries is rarely published. Thus, the US drug sales data is used as a substitute measurement. A US-based healthcare information company, IMS Health, publishes the national sales of top therapeutic drugs in the US. This data is then matched with the 22 patent subclasses of drugs (from A61P 1/00 to A61P 43/00).

The revenue is also determined by the strictness of the patent law implement. According to the OECD (2008, p.107) it is often negatively correlated with the General Trade-Related Index of Counterfeiting for economies (GTRIC-e). The GTRIC-e scores for China, Korea and Japan are 0.9748, 0.6085 and 0.0419, respectively. Larger scores indicate a weaker level of patent protection. The score GTRIC-e for a patent is the maximum value of all the scores of countries where the patent is filed. For example, if patent $i$ is filed in both Japan and China, then GTRIC- $e_{i}$ is set to 0.9748. If a company takes the risk to lodge a patent application in a high scored GTRIC-e country, then this company can be reasonably believed to be more prepared in anti-counterfeiting than those not entering this country. Therefore, the GTRIC- $\mathrm{e}_{i}$ score assigned to the corresponding company indicates this company's capability in coping with counterfeiting ${ }^{2}$.

As mentioned before, the cost of lodging a patent application is related to whether this company has subsidiaries in the host country as well as the firm size. First, an explanatory variable is constructed to control for the existence of subsidiaries of a pharmaceutical company in the three host countries (host_subsidiary). Then, the size of a company (firm_size) can be captured by the number of employees in that company. 1,298 patents out of the 1,994 total samples are successfully matched

\footnotetext{
${ }^{2}$ There is more than one way of interpreting this score. If a company gives up entering a country with lower level of intellectual property protection, then the less GTRIC-e score is assigned to a company. Thus, the GTRIC-e score also measures a company’s degree of risk-aversion of counterfeiting.
} 
with those in MintGlobal, a comprehensive information database of companies worldwide. Those 1,298 patents are owned by 387 MNC subsidiaries or independent companies.

Besides host_subsidiary and firm_size, there are other firm specific characteristics which may affect the propensity of patenting, for example, technological advancement or leadership in a field and the total number of patents that a firm holds. However, pharmaceutical industry is a segmented sector. For example, a leading company in digestive drugs may be inactive in the research of cardiovascular medicine. Similarly, a firm holding a large number of patents in nervous field cannot be simply put as a stronger competitor than another firm which holds a small number of patents in metabolism medicine. Therefore, these characteristics are excluded in the econometric models.

Finally, the degree of patent policy discrimination perceived by an applicant can be measured by the grant rate (grant_rate) of previous patent applications lodged by the same applicant. To construct grant_rate, the worldwide patent applications of the 387 companies are extracted from the PATSTAT database. Since these inventions in the sample are all approved by FDA, it is reasonable to believe that these patents are all high-quality patents. Therefore, if any of those patents are rejected in Korea, China or Japan, the applicant will possibly interpret it as a signal of discrimination. The purpose of this paper is to observe whether applicants will respond to a smaller grant_rate by submitting fewer applications for new patents (appln_times) after controlling for the other factors (market_size, host_subsidiary and firm_size).

Table 1 lists the definitions of the variables and some summary statistics. Only 254 of the 387 patent owners have their number of employees recorded in the MintGlobal database. As a result, 
only 944 patents can be matched with an employee number. It is noted that there is considerable variation in employee numbers. Thus, given the large scale of its mean and variation, the logarithm of the actual employee number is used in the regressions.

Table 1 Summary of the variables

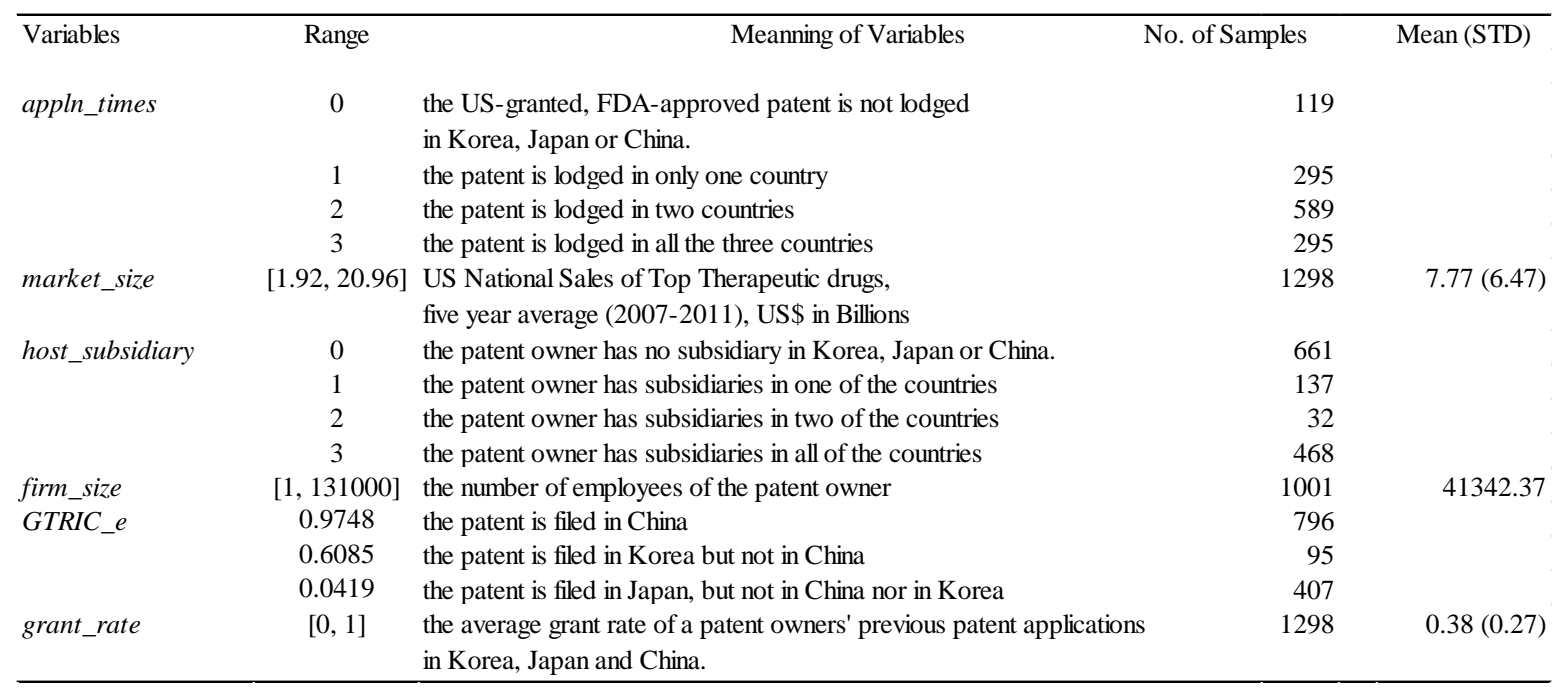

\section{Regression Results and Discussions}

The regression results for the ordered Logit model are listed in the first column of Table 2. The ordered Logit model has a built-in assumption which requires the coefficients to be equal across the levels of the outcome. In another word, vector $\mathbf{B}$ in Equations (1) - (4) is identical. For this reason, this model is also known as the proportional-odds model. The Brant test for the proportional odds assumption rejects the null hypothesis (Brant, 1990). This means that the coefficients are not equal across the levels of the outcome.

If the data does not fit the proportional-odds model, then a less restrictive one, partial proportional odds model (PPOM), is often used (Hauser and Andrew, 2006; Williams, 2006). However, recently a new framework has been developed, which contributes to the violation of the proportional-odds 
assumption as to the nature of heteroskedasticity (Williams, 2010). This framework is coined as the ordinal generalized linear model (OGLM). The rationales which motivate the PPOM and OGLM are very different. Once the odds are detected as not being proportional in the PPOM, they are interpreted as a matter of fact. However, the OGLM suggests that the real coefficients may be proportional, but it is the heteroskedasticity that skew the estimated coefficients to be partial proportional.

Table 2 Regression results

\begin{tabular}{|c|c|c|c|}
\hline Parameter & Ordered Logit & OGLM & PPOM \\
\hline$\alpha_{1}$ & $0.64(0.32)^{* *}$ & $0.59(0.30)^{* * *}$ & $0.07(0.44)^{* * *}$ \\
\hline$\alpha_{2}$ & $6.70(0.89)^{* * *}$ & $5.77(1.36)$ & $7.90(1.29)^{* * *}$ \\
\hline$\alpha_{3}$ & $14.56(1.50)^{* * *}$ & $12.49(-2.81)$ & $14.82(1.53)^{* * *}$ \\
\hline market_size & $0.00(0.01)$ & $0.00(0.01)^{* * *}$ & $0.00(0.01)$ \\
\hline host_subsidiary & $0.14(0.07)^{* *}$ & $0.12(0.06)^{* * *}$ & $0.15(0.07)^{* *}$ \\
\hline firm_size $_{1}$ & & & $-0.15(0.05)^{* * *}$ \\
\hline firm_size 2 & $-0.09(0.03)^{* *}$ & $-0.07(0.03)^{* * *}$ & $0.06(0.11)$ \\
\hline firm_size $_{3}$ & & & $-0.06(0.04)$ \\
\hline grant_rate & $0.57(0.26)^{* *}$ & $0.53(0.25)^{* * *}$ & $0.59(0.27)^{* *}$ \\
\hline GTRIC_e & $14.79(1.52) * * *$ & $12.61(2.81)^{* * *}$ & $14.80(1.54)^{* * *}$ \\
\hline Brant Test & $26.54 * * *$ & -- & -- \\
\hline firm_size & $14.88 * * *$ & -- & -- \\
\hline grant_rate & $13.06 * * *$ & -- & -- \\
\hline \multicolumn{4}{|l|}{ Heteroskedasticity Test } \\
\hline firm_size & -- & $-0.41(0.24)$ & -- \\
\hline grant_rate & -- & $0.00(0.02)^{* * *}$ & -- \\
\hline No. of Samples & 944 & 944 & 944 \\
\hline
\end{tabular}

Notes: Standard errors in parentheses. ${ }^{* * *}$ and ${ }^{* *}$ indicate significance at the $1 \%$ and $5 \%$ level, respectively. Source: Authors' own calculation using the PATSTAT and MintGlobal databases.

Empirically, there is no way to distinguish which model is better. Thus, in a classic PPOM regression every explanatory variable will have three levels, which are corresponding to the three levels of the responsive variable "appln_times”. However, the Brant test of individual explanatory variables reveals only grant_rate and firm_size violate the proportional-odds assumption. A further 
test in OGLM shows that grant_rate is more likely the single cause of heteroskedasticity. Combining these results, it seems a PPOM regression which frees firm_size from the parallel-lines assumption would be an appropriate choice. As a result, only the estimated coefficients of variable firm_size are split into three levels. In fact, the estimated coefficients of the three models do not vary greatly. Hence, the regression results are found to be robust with different model specifications.

The interpretation of the estimated coefficients is straightforward. For example, the estimated coefficient of grant_rate is 0.59 in the PPOM column. It suggests if the grant_rate of a company's past patents were to be increased by 0.1 , the log-odds for the company to lodge a new patent application would be expected to increase by 0.059 units, certeris paribus. Thus, it suggests that the grant_rate of past applications is an important factor affecting a company's decision to lodge a new patent application. This finding implies that if a country adopts a discriminatory patent policy, foreign inventors will be less likely to lodge a new application. Therefore, it suggests even if a discriminatory policy fosters a domestic firm to catch up advanced technology (Yu and Wu, 2013), this policy has an upper bound. If it is overused, the side effects of reducing foreign advanced patent applications can overwhelm the benefits. An extreme example is observed in India where pharmaceutical firms only became active in filing patents after India started to grant pharmaceutical product patents to foreign applicants in 2004 (Chadha 2009).

The strictness in executing the patent law is also a key factor. In this paper GTRIC-e is used to measure an applicants' degree of risk-aversion of counterfeiting. Thus, the positive estimations of GTRIC-e imply that if an applicant is more concerned with counterfeiting (smaller GTRIC-e score), 
then the applicant will be less likely to lodge a patent in China or Korea (smaller appln_times). The policy makers in those countries are more lenient with counterfeiting in contrast to their counterparts in Japan and the US. Therefore, the regression results demonstrate that less strict patent law implementation does have a significant blocking effect on foreign patenting.

Another factor affecting a foreign company's decision to lodge a new patent application is whether the company has established a subsidiary in the host country. The estimated coefficients of host_subsidiary in the two multinomial Logit models are all significantly positive, which suggests subsidiaries do play a significant role in assisting the acquisition of patents in their host countries. This result is confirmed by Bergek and Bruzelius (2010) who investigated a multinational corporation and found that the majority of its cross-border patents is due to inter-subsidiary collaboration.

As for the market size, most of the estimated coefficients in the two multinomial Logit models are not significant. However, this may be caused by the poor measure of market size. Because of the lack of drug sales data in Japan, Korea and China, the sales in the US were used as the measure. Nonetheless, this measure can be biased if there is large heterogeneity across countries. According to a World Health Organization report (WHO, 1998, p.44), infectious and parasitic diseases caused 43 percent of the deaths in developing countries, but they only caused 1 percent of the deaths in developed countries in 1997. Thus, the measure of drug sales in the US may be inadequate in capturing the market size of different drugs in Japan, Korea and China. Therefore, it cannot be asserted that market size does not affect patenting behavior.

Furthermore, the estimated coefficients of firm_size seem to be controversial. It is expected that 
larger firms will be more active in lodging patent applications. In contrast, the regression results suggest the effect of firm_size is either negative (in OGLM) or non-linear (in PPOM). Previous studies have also identified a nonlinear relationship between firm size and overseas innovations (e.g. Belderbos, 2001), which suggests a fundamental twist may exist. A possible explanation lies in the characteristics of the pharmaceutical industry. Goldberg (2010) observes that new drugs are usually not launched by the multinational patent-holders in India, but by domestic firms. She explains this phenomenon by "global reference pricing”, in which prices in India may be used as a reference point for the setting of prices in developed countries. Multinational corporations like to delay their entry into developing country markets, where prices are capped by the limited purchasing power of domestic consumers, until they have negotiated prices with higher income countries. Accordingly, "global reference pricing” can explain the negative estimated coefficients of firm_size. Compared with the United States, United Kingdom, Canada, and Germany, the price regulation of drugs in Japan, Korea and China is very strict (Danzon and Chao, 2000; Kyle, 2007). Thus, large multinational corporations have a motive to postpone the patent application of their blockbuster drugs in Japan, Korea and China, as the foregone profits in these markets are much smaller than the additional profits to be accrued in western markets.

Finally, to check the robustness of the findings, a couple of tests are conducted. In the preceding section, our discussions are based on a partial proportional odds model (PPOM) which lies in between two “extreme” models. One is the ordered Logit (OL) model, which takes identical estimates for variables in concern; and the other is the multinomial Logit (ML) model, which removes this restriction. Though the OL and ML models may not fit our dataset, they are still useful alternatives which are estimated for checking the robustness of the PPOM estimates. Table 3 
demonstrates the regression results of the PPOM do not systematically differ from its two extremes (OL and ML models). The estimates remain in the same scales and the signs do not change as well.

Table 3 Regression results for robustness test

\begin{tabular}{|c|c|c|c|c|c|c|}
\hline Parameter & \multicolumn{2}{|c|}{ Ordered Logit } & \multicolumn{2}{|c|}{ РPOM } & \multicolumn{2}{|c|}{ Multinomial Logit (ML) } \\
\hline$\alpha_{1}$ & 0.64 & $(0.32)^{* *}$ & 0.07 & $(0.44)^{* * *}$ & 0.58 & $(0.28)^{* *}$ \\
\hline$\alpha_{2}$ & 6.70 & $(0.89)^{* * *}$ & 7.90 & $(1.29)^{* * *}$ & 5.71 & $(0.88)^{* * *}$ \\
\hline$\alpha_{3}$ & 14.56 & $(1.50)^{* * *}$ & 14.82 & $(1.53)^{* * *}$ & 12.36 & $(1.65)^{* * *}$ \\
\hline market_size $_{1}$ & & & & & 0.01 & $(0.02)$ \\
\hline market_size $_{2}$ & 0.00 & $(0.01)$ & 0.00 & $(0.01)$ & 0.03 & $(0.02)^{*}$ \\
\hline market_size 3 & & & & & 0.01 & $(0.02)$ \\
\hline host_subsidiary 1 & & & & & 0.38 & $(0.22)^{*}$ \\
\hline host_subsidiary 2 & 0.14 & $(0.07)^{* *}$ & 0.15 & $(0.07)^{* *}$ & 0.37 & $(0.20)^{*}$ \\
\hline host_subsidiary 3 & & & & & 0.45 & $(0.21)^{* *}$ \\
\hline firm_size $_{1}$ & & & -0.15 & $(0.05)^{* * *}$ & -0.02 & $(0.01)^{* *}$ \\
\hline firm_size $_{2}$ & -0.09 & $(0.03)^{* *}$ & 0.06 & $(0.11)$ & -0.02 & $(0.01)^{*}$ \\
\hline firm_size $_{3}$ & & & -0.06 & $(0.04)$ & -0.02 & $(0.01)^{*}$ \\
\hline grant_rate $_{1}$ & & & & & 1.06 & $(0.41)^{* * *}$ \\
\hline grant_rate $_{2}$ & 0.57 & $(0.26)^{* *}$ & 0.59 & $(0.27)^{* *}$ & 0.74 & $(0.38)^{*}$ \\
\hline grant_rate $_{3}$ & & & & & 0.80 & $(0.41)^{*}$ \\
\hline GTRIC_e & 14.79 & $(1.52)^{* * *}$ & 14.80 & $(1.54)^{* * *}$ & 12.48 & $(1.71)^{* * *}$ \\
\hline
\end{tabular}

Notes: Standard errors in parentheses. *, ** and ***indicate significance at the $10 \%, 5 \%$ and $1 \%$ level, respectively.

Source: Authors’ own calculation using the PATSTAT and MintGlobal databases.

\section{Conclusions}

This paper examined how foreign patent applicants could respond to discriminatory treatment in host countries. To investigate this question, firm-level information is needed. Therefore, this study concentrates on pharmaceutical companies with patents granted by the US patent office and approved by the US FDA. It particularly focuses on the filing behavior of those pharmaceutical companies in the Japanese, Korean and Chinese patent offices.

The regression results suggest that the treatment of past applications in a host country seems to be a 
key factor affecting a company's decision whether to lodge a new patent application or not. In addition, a company is more likely to lodge a new patent application if it establishes a subsidiary in the host country. The market share of the pharmaceutical products and the firm size are also considered as the control variables. However, no decisive conclusion can be drawn in regard to both factors.

This research contributes to the recently heated discussion about discriminatory patent policy. As revealed in previous studies, foreign patent applications tend to face longer pendency and a greater rejection rate than domestic patents in certain countries. The motive of this kind of policy could be further connected with strategic trade behavior which aims to stimulate the domestic firms' catching-up in technology (Yu and $\mathrm{Wu}, 2013$ ). However, this research shows that discriminatory patent policies have a limited scope, because strong discrimination can result in foreign applicants' retaliation by reducing their new applications.

\section{Acknowledgements:}

We thank an anonymous referee for helpful comments. Work on this paper started while the first author was studying in the Business School, University of Western Australia. His study was jointly sponsored by China Scholarship Council and UWA Business School. We would like to acknowledge the generous financial support from these institutions. 


\section{References}

Belderbos, R., 2001. Overseas innovations by Japanese firms: An analysis of patent and subsidiary data. Research Policy 30, 313-332.

Bergek, A., Bruzelius, M., 2010. Are patents with multiple inventors from different countries a good indicator of international R\&D collaboration? The case of ABB. Research Policy 39, 1321-1334.

Chadha, A., 2009. Trips and patenting activity: Evidence from the Indian pharmaceutical industry. Economic Modelling 26, 499-505.

Chen, X., Zhang, C., 2006. American pharmaceutical companies dominate applications for patents in china. China Economist, 98-107.

Danguy, J., van Pottelsberghe de la Potterie, B., 2011. Patent fees for a sustainable EU patent system. World Patent Information 33(3), 240-247.

Danzon, P.M., Chao, L.-W., 2000. Does regulation drive out competition in pharmaceutical markets? Journal of Law and Economics 43, 311-357.

Goldberg, P.K., 2010. Intellectual property rights protection in developing countries: The case of pharmaceuticals. Journal of the European Economic Association 8, 326-353.

Kotabe, M., 1992. A comparative study of U.S. and Japanese patent systems. Journal of International Business Studies 23, 147-168.

Kyle, M.K., 2007. Pharmaceutical price controls and entry strategies. Review of Economics and Statistics 89, 88-99.

Lemley, M. A., Sampat, B., 2012. Examiner characteristics and patent office outcomes. The Review of Economics and Statistics 94(3): 817-827.

Li, X., 2008. The impact of higher standards in patent protection for pharmaceutical industries 
under the trips agreement - a comparative study of China and India. World Economy 31, 1367-1382.

OECD, 2008. The economic impact of counterfeiting and piracy. Source OECD.

Qian, Y., 2007. Do national patent laws stimulate domestic innovation in a global patenting environment? A cross-country analysis of pharmaceutical patent protection, 1978-2002. Review of Economics and Statistics 89, 436-453.

Rassenfosse, G., van Pottelsberghe de la Potterie, B., 2013. The role of fees in patent systems: theory and evidence. Journal of Economic Surveys 27(4), 696-716.

Rassenfosse, G., van Pottelsberghe de la Potterie, B., 2012. On the price elasticity of demand for patents. Oxford Bulletin of Economics and Statistics 74(1), 58-77.

Webster, E., Palangkaraya, A., Jensen, P.H., 2007. Characteristics of international patent application outcomes. Economics Letters 95, 362-368.

WHO, 1998. Life in the 21st century: A vision for all. World Health Organization.

WIPO, 2016, "Section C: Chemistry; Metallurgy”, in International Patent Classification (IPC) Official Publication, World Intellectual Property Organization (http://www.wipo.int/classifications/ipc/en/).

Wooldridge, J.R.M., 2002. Econometric analysis of cross section and panel data. The MIT Press, Massachusetts.

Yang, D., 2008. Pendency and grant ratios of invention patents: A comparative study of the US and China. Research Policy 37, 1035-1046.

Yu, F., Wu, Y., 2013. Patent examination and disguised protection. Economics Discussion / Working Papers 13-07, The University of Western Australia, Department of Economics.

Zhang, G., Chen, X., 2012. The value of invention patents in china: Country origin and technology field differences. China Economic Review 23(2), 357-370 
Editor, UWA Economics Discussion Papers:

Sam Hak Kan Tang

University of Western Australia

35 Sterling Hwy

Crawley WA 6009

Australia

Email: ecoadmin@biz.uwa.edu.au

The Economics Discussion Papers are available at:

1980 - 2002: $\quad$ http://ecompapers.biz.uwa.edu.au/paper/PDF\%20of\%20Discussion\%20Papers/

Since 2001: $\quad$ http://ideas.repec.org/s/uwa/wpaper1.html

Since 2004: $\quad$ http://www.business.uwa.edu.au/school/disciplines/economics

\begin{tabular}{|c|c|c|}
\hline \multicolumn{3}{|c|}{$\begin{array}{l}\text { ECONOMICS DISCUSSION PAPERS } \\
2015\end{array}$} \\
\hline $\begin{array}{l}\text { DP } \\
\text { NUMBER }\end{array}$ & AUTHORS & TITLE \\
\hline 15.01 & Robertson, P.E. and Robitaille, M.C. & $\begin{array}{l}\text { THE GRAVITY OF RESOURCES AND THE TYRANNY OF } \\
\text { DISTANCE }\end{array}$ \\
\hline 15.02 & Tyers, R. & $\begin{array}{l}\text { FINANCIAL INTEGRATION AND CHINA'S GLOBAL } \\
\text { IMPACT }\end{array}$ \\
\hline 15.03 & Clements, K.W. and Si, J. & $\begin{array}{l}\text { MORE ON THE PRICE-RESPONSIVENESS OF FOOD } \\
\text { CONSUMPTION }\end{array}$ \\
\hline 15.04 & Tang, S.H.K. & $\begin{array}{l}\text { PARENTS, MIGRANT DOMESTIC WORKERS, AND } \\
\text { CHILDREN'S SPEAKING OF A SECOND LANGUAGE: } \\
\text { EVIDENCE FROM HONG KONG }\end{array}$ \\
\hline 15.05 & Tyers, R. & $\begin{array}{l}\text { CHINA AND GLOBAL MACROECONOMIC } \\
\text { INTERDEPENDENCE }\end{array}$ \\
\hline 15.06 & $\begin{array}{l}\text { Fan, J., Wu, Y., Guo, X., Zhao, D. } \\
\text { and Marinova, D. }\end{array}$ & $\begin{array}{l}\text { REGIONAL DISPARITY OF EMBEDDED CARBON } \\
\text { FOOTPRINT AND ITS SOURCES IN CHINA: A } \\
\text { CONSUMPTION PERSPECTIVE }\end{array}$ \\
\hline 15.07 & $\begin{array}{l}\text { Fan, J., Wang, S., Wu, Y., Li, J. and } \\
\text { Zhao, D. }\end{array}$ & $\begin{array}{l}\text { BUFFER EFFECT AND PRICE EFFECT OF A PERSONAL } \\
\text { CARBON TRADING SCHEME }\end{array}$ \\
\hline 15.08 & Neill, K. & $\begin{array}{l}\text { WESTERN AUSTRALIA'S DOMESTIC GAS } \\
\text { RESERVATION POLICY THE ELEMENTAL ECONOMICS }\end{array}$ \\
\hline 15.09 & Collins, J., Baer, B. and Weber, E.J. & THE EVOLUTIONARY FOUNDATIONS OF ECONOMICS \\
\hline 15.10 & $\begin{array}{l}\text { Siddique, A., Selvanathan, E. A. and } \\
\text { Selvanathan, S. }\end{array}$ & $\begin{array}{l}\text { THE IMPACT OF EXTERNAL DEBT ON ECONOMIC } \\
\text { GROWTH: EMPIRICAL EVIDENCE FROM HIGHLY } \\
\text { INDEBTED POOR COUNTRIES }\end{array}$ \\
\hline 15.11 & Wu, Y. & $\begin{array}{l}\text { LOCAL GOVERNMENT DEBT AND ECONOMIC } \\
\text { GROWTH IN CHINA }\end{array}$ \\
\hline 15.12 & Tyers, R. and Bain, I. & $\begin{array}{l}\text { THE GLOBAL ECONOMIC IMPLICATIONS OF FREER } \\
\text { SKILLED MIGRATION }\end{array}$ \\
\hline 15.13 & Chen, A. and Groenewold, N. & $\begin{array}{l}\text { AN INCREASE IN THE RETIREMENT AGE IN CHINA: } \\
\text { THE REGIONAL ECONOMIC EFFECTS }\end{array}$ \\
\hline 15.14 & Knight, K. & PIGOU, A LOYAL MARSHALLIAN? \\
\hline 15.15 & Kristoffersen, I. & $\begin{array}{l}\text { THE AGE-HAPPINESS PUZZLE: THE ROLE OF } \\
\text { ECONOMIC CIRCUMSTANCES AND FINANCIAL } \\
\text { SATISFACTION }\end{array}$ \\
\hline
\end{tabular}




\begin{tabular}{|c|c|c|}
\hline 15.16 & Azwar, P. and Tyers, R. & INDONESIAN MACRO POLICY THROUGH TWO CRISES \\
\hline 15.17 & Asano, A. and Tyers, R. & $\begin{array}{l}\text { THIRD ARROW REFORMS AND JAPAN'S ECONOMIC } \\
\text { PERFORMANCE }\end{array}$ \\
\hline 15.18 & Arthmar, R. and McLure, M. & $\begin{array}{l}\text { ON BRITAIN'S RETURN TO THE GOLD STANDARD: } \\
\text { WAS THERE A 'PIGOU-MCKENNA SCHOOL’? }\end{array}$ \\
\hline 15.19 & $\begin{array}{l}\text { Fan, J., Li, Y., Wu, Y., Wang, S., and } \\
\text { Zhao, D. }\end{array}$ & $\begin{array}{l}\text { ALLOWANCE TRADING AND ENERGY CONSUMPTION } \\
\text { UNDER A PERSONAL CARBON TRADING SCHEME: A } \\
\text { DYNAMIC PROGRAMMING APPROACH }\end{array}$ \\
\hline 15.20 & Shehabi, M. & $\begin{array}{l}\text { AN EXTRAORDINARY RECOVERY: KUWAIT } \\
\text { FOLLOWING THE GULF WAR }\end{array}$ \\
\hline 15.21 & $\begin{array}{l}\text { Siddique, A., Sen, R., and } \\
\text { Srivastava, S. }\end{array}$ & $\begin{array}{l}\text { AUSTRALIA-THAILAND TRADE: AN ANALYSIS OF } \\
\text { COMPETITIVENESS AND THE EFFECTS OF THE } \\
\text { BILATERAL FTA }\end{array}$ \\
\hline 15.22 & Tyers, R. & $\begin{array}{l}\text { SLOWER GROWTH AND VULNERABILITY TO } \\
\text { RECESSION: UPDATING CHINA'S GLOBAL IMPACT }\end{array}$ \\
\hline 15.23 & Arthmar, R. and McLure, M. & PIGOU ON WAR FINANCE AND STATE ACTION \\
\hline 15.24 & Wu, Y. & $\begin{array}{l}\text { CHINA'S CAPITAL STOCK SERIES BY REGION AND } \\
\text { SECTOR }\end{array}$ \\
\hline 15.25 & Clements, K. and Si, J. & $\begin{array}{l}\text { ENGEL'S LAW, DIET DIVERSITY AND THE QUALITY OF } \\
\text { FOOD CONSUMPTION }\end{array}$ \\
\hline 15.26 & Chen, S. & $\begin{array}{l}\text { SHIFTS OF DISTORTION AND CORRUPTION OVER } \\
\text { LOCAL POLITICAL CYCLES IN CHINA }\end{array}$ \\
\hline 15.27 & Chen, S. & $\begin{array}{l}\text { THE EFFECT OF A FISCAL SQUEEZE ON TAX } \\
\text { NFORCEMENT: EVIDENCE FROM A NATURAL } \\
\text { EXPERIMENT IN CHINA }\end{array}$ \\
\hline 15.28 & Jetter, M. & $\begin{array}{l}\text { BLOWING THINGS UP: THE EFFECT OF MEDIA } \\
\text { ATTENTION ON TERRORISM }\end{array}$ \\
\hline 15.29 & Tang, S. & $\begin{array}{l}\text { MEDIUM-TERM MACROECONOMIC VOLATILITY AND } \\
\text { ECONOMIC DEVELOPMENT: A NEW TECHNIQUE }\end{array}$ \\
\hline 15.30 & Alim, A., Hartley, P. and Lan, Y. & $\begin{array}{l}\text { ASIAN SPOT PRICES FOR LNG OTHER ENERGY } \\
\text { COMMODITIES }\end{array}$ \\
\hline 15.31 & $\begin{array}{l}\text { Gannon, B., Harris, D., Harris, M., } \\
\text { Magnusson, L., Hollingsworth, B., } \\
\text { Inder, B., Maitra, P, and Munford, L. }\end{array}$ & $\begin{array}{l}\text { NEW APPROACHES TO ESTIMATING THE CHILD } \\
\text { HEALTH-PARENTAL INCOME RELATIONSHIP }\end{array}$ \\
\hline 15.32 & Czaika, M. and Parsons, C. & $\begin{array}{l}\text { THE GRAVITY OF HIGH SKILLED MIGRATION } \\
\text { POLICIES }\end{array}$ \\
\hline 15.33 & $\begin{array}{l}\text { Parsons, C., Rojon, S., Samanani, F, } \\
\text { and Wettach, L. }\end{array}$ & $\begin{array}{l}\text { CONCEPTUALISING INTERNATIONAL HIGH-SKILLED } \\
\text { MIGRATION }\end{array}$ \\
\hline 15.34 & Chen, S. & $\begin{array}{l}\text { VAT RATE DISPERSION AND TFP LOSS IN CHINA'S } \\
\text { MANUFACTURING SECTOR }\end{array}$ \\
\hline 15.35 & $\begin{array}{l}\text { Tait, L., Siddique, A. and } \\
\text { Chatterjee, I. }\end{array}$ & $\begin{array}{l}\text { FOREIGN AID AND ECONOMIC GROWTH IN } \\
\text { SUB-SAHARAN AFRICA }\end{array}$ \\
\hline
\end{tabular}




\begin{tabular}{|c|c|c|}
\hline \multicolumn{3}{|c|}{$\begin{array}{l}\text { ECONOMICS DISCUSSION PAPERS } \\
2016\end{array}$} \\
\hline $\begin{array}{l}\text { DP } \\
\text { NUMBER }\end{array}$ & AUTHORS & TITLE \\
\hline 16.01 & Xu, R., Wu, Y. and Luan, J. & $\begin{array}{l}\text { ANALYSIS OF FARMERS' WILLINGNESS TO ADOPT } \\
\text { GENETICALLY MODIFIED INSECT-RESISTANT RICE IN } \\
\text { CHINA }\end{array}$ \\
\hline 16.02 & $\begin{array}{l}\text { Lia, Y., Fan, J., Zhao, D., Wu, Y. and } \\
\text { Li, J. }\end{array}$ & $\begin{array}{l}\text { TIERED GASOLINE PRICING: A PERSONAL CARBON } \\
\text { TRADING PERSPECTIVE }\end{array}$ \\
\hline 16.03 & Clements, K.W., Lan, Y. and Si, J. & UNCERTAINTY IN CURRENCY MISPRICING \\
\hline 16.04 & Parsons, C. and Vézina, P.L. & $\begin{array}{l}\text { MIGRANT NETWORKS AND TRADE:THE VIETNAMESE } \\
\text { BOAT PEOPLE AS A NATURAL EXPERIMENT }\end{array}$ \\
\hline 16.05 & Chang, S., Connelly, R. and Ma, P. & $\begin{array}{l}\text { WHAT WILL YOU DO IF I SAY 'I DO’?: THE EFFECT OF } \\
\text { THE SEX RATIO ON TIME USE WITHIN TAIWANESE } \\
\text { MARRIED COUPLES }\end{array}$ \\
\hline 16.06 & Yu, F. and Wu, Y. & $\begin{array}{l}\text { BIASES IN PATENT EXAMINATION AND FIRMS' } \\
\text { RESPONSES: EVIDENCE FROM THE } \\
\text { PHARMACEUTICAL INDUSTRY }\end{array}$ \\
\hline 16.07 & $\begin{array}{l}\text { Fan, J., Li, J., Wu, Y., Wang, S. and } \\
\text { Zhao, D. }\end{array}$ & $\begin{array}{l}\text { THE EFFECTS OF ALLOWANCE PRICE ON ENERGY } \\
\text { DEMAND UNDER A PERSONAL CARBON TRADING } \\
\text { SCHEME }\end{array}$ \\
\hline 16.08 & Golley, J., Tyers, R. and Zhou, Y. & $\begin{array}{l}\text { CONTRACTIONS IN CHINESE FERTILITY AND } \\
\text { SAVINGS: LONG RUN DOMESTIC AND GLOBAL } \\
\text { IMPLICATIONS }\end{array}$ \\
\hline 16.09 & McGrath, G. and Neill, K. & $\begin{array}{l}\text { FOREIGN AND DOMESTIC OWNERSHIP IN WESTERN } \\
\text { AUSTRALIA’S GAS MARKET }\end{array}$ \\
\hline 16.10 & Clements, K.W. and Si, J. & SIMPLIFYING THE BIG MAC INDEX \\
\hline 16.11 & Priyati, R.Y. and Tyers, R. & $\begin{array}{l}\text { PRICE RELATIONSHIPS IN VEGETABLE OIL AND } \\
\text { ENERGY MARKETS }\end{array}$ \\
\hline 16.12 & Wu, J., Wu, Y. and Wang, B. & $\begin{array}{l}\text { THE GREENNESS OF CHINESE CITIES: CARBON } \\
\text { DIOXIDE EMISSION AND ITS DETERMINANTS }\end{array}$ \\
\hline 16.13 & $\begin{array}{l}\text { Arslan, C., Dumont, J.C., Kone, Z., } \\
\text { Özden, C.., Parsons, C. and } \\
\text { Xenogiani, T. }\end{array}$ & $\begin{array}{l}\text { INTERNATIONAL MIGRATION TO THE OECD IN THE } \\
\text { TWENTY-FIRST CENTURY }\end{array}$ \\
\hline 16.14 & Tomioka, K. and Tyers, R. & $\begin{array}{l}\text { HAS FOREIGN GROWTH CONTRIBUTED TO } \\
\text { STAGNATION AND INEQUALITY IN JAPAN? }\end{array}$ \\
\hline 16.15 & Donovan, J. and Hartley, P. & $\begin{array}{l}\text { RIDING THE IRON ORE CYCLE: ACTIONS OF } \\
\text { AUSTRALIA'S MAJOR PRODUCERS }\end{array}$ \\
\hline
\end{tabular}

